\title{
DISTRIBUTION AND MOVEMENT OF BIG SPRING SPINEDACE (LEPIDOMEDA MOLLISPINIS PRATENSIS) IN CONDOR CANYON, MEADOW VALLEY WASH, NEVADA
}

\author{
Ian G. Jezorek ${ }^{1,2}$ and Patrick J. Connolly ${ }^{1}$
}

\begin{abstract}
Big Spring spinedace (Lepidomeda mollispinis pratensis) is a cyprinid whose entire population occurs within a section of Meadow Valley Wash, Nevada. Other spinedace species have suffered population and range declines (one species is extinct). Managers, concerned about the vulnerability of Big Spring spinedace, have considered habitat restoration actions or translocation, but they have lacked data on distribution or habitat use. Our study occurred in an $8.2-\mathrm{km}$ section of Meadow Valley Wash, including about $7.2 \mathrm{~km}$ in Condor Canyon and $0.8 \mathrm{~km}$ upstream of the canyon. Big Spring spinedace were present upstream of the currently listed critical habitat, including in the tributary Kill Wash. We found no Big Spring spinedace in the lower $3.3 \mathrm{~km}$ of Condor Canyon. We tagged Big Spring spinedace $\geq 70 \mathrm{~mm}$ fork length (range 70-103 mm) with passive integrated transponder tags during October $2008(n=100)$ and March 2009 $(n=103)$ to document movement. At least 47 of these individuals moved from their release location (up to $2 \mathrm{~km}$ ). Thirty-nine individuals moved to Kill Wash or the confluence area with Meadow Valley Wash. Ninety-three percent of movement occurred in spring 2009. Fish moved both upstream and downstream. We found no movement downstream over a small waterfall at river km 7.9 and recorded only one fish that moved downstream over Delmue Falls (a 12-m drop) at river $\mathrm{km} \mathrm{6.1.} \mathrm{At} \mathrm{the} \mathrm{time} \mathrm{of} \mathrm{tagging,} \mathrm{there} \mathrm{was} \mathrm{no} \mathrm{significant} \mathrm{difference} \mathrm{in} \mathrm{fork} \mathrm{length} \mathrm{or} \mathrm{condition} \mathrm{between} \mathrm{Big}$ Spring Spinedace that were later detected moving and those not detected moving. We found no significant difference in fork length or condition at time of tagging of Big Spring spinedace $\geq 70 \mathrm{~mm}$ fork length that were detected moving and those not detected moving. Kill Wash and its confluence area appeared important to Big Spring spinedace; connectivity with these areas may be key to species persistence. These areas may provide a habitat template for restoration or translocation. The lower $3.3 \mathrm{~km}$ of Meadow Valley Wash in Condor Canyon may be a good candidate section for habitat restoration actions.
\end{abstract}

REsumen.-El pez Big Spring spinedace (Lepidomeda mollispinis pratensis) es un ciprínido cuya población completa se encuentra en una sección del arroyo Meadow Valley Wash, Nevada. Otras especies de spinedace han sufrido una disminución en la población y en el área (una de las especies se encuentra en extinción). Si bien los directores de los espacios de conservación del hábitat, que estaban preocupados por la posible extinción de Big Spring spinedace, se propusieron poner en práctica obras de restauración del hábitat y de traslado, no contaron con la suficiente información sobre la distribución o la utilización del hábitat. Nuestro estudio se realizó en una sección de Meadow Valley Wash que tiene una longitud de $8.2 \mathrm{~km}$, incluyendo aproximadamente $7.2 \mathrm{~km}$ en Condor Canyon y $0.8 \mathrm{~km}$ a contracorriente del barranco. Se encontró Big Spring spinedace a contracorriente del hábitat que se considera crítico, y en el afluente Kill Wash. No encontramos Big Spring spinedace en la parte baja de $3.3 \mathrm{~km}$ de Condor Canyon. Realizamos el marcado de Big Spring spinedace con un largo de horquila de $\geq 70 \mathrm{~mm}$ (rango 70-103 mm) con Transmisores Integrados Pasivos durante octubre del año $2008(n=100)$ y marzo del año $2009(n=103)$ para documentar los patrones de movimiento. Por lo menos 47 de estos individuos se trasladaron desde el lugar de donde partieron (hasta $2 \mathrm{~km}$ ) a otros lugares. Treinta y nueve individuos se trasladaron a Kill Wash o al área de confluencia con Meadow Valley Wash. El 93\% del movimiento se observó durante la primavera del año 2009. Los peces se trasladaron en las dos direcciones, contra la corriente y río abajo. No observamos movimiento río abajo en una pequeña catarata en un trayecto de 7.9 kilómetros de río y registramos que sólo un pez se trasladó río abajo a lo largo de Delmue Falls (con una caída de 12 m) en un trayecto de 6.1 kilómetros de río. No observamos diferencias significativas en el largo de horquila o las condiciones en el momento de realizar el marcado de los Big Spring spinedace de $70 \mathrm{~mm}$ de distancia focal o de mayor tamaño que se detectaron en movimiento y los que no se detectaron en movimiento. Kill Wash y su área de confluencia parecen ser factores importantes para el Big Spring spinedace, y, por lo tanto, es posible que la conectividad con estas áreas sea clave para la persistencia de las especies. Estas áreas representan un ejemplo de hábitat propicio para la restauración o el traslado. La parte baja de $3.3 \mathrm{~km}$ de Meadow Valley Wash en Condor Canyon puede ser un área apropiado para realizar acciones de restauración del hábitat.

Population and range declines have been desert southwest of the United States, often a recorded for many native fish species of the result of anthropogenic effects on landscape

\footnotetext{
${ }^{1}$ U.S. Geological Survey, Western Fisheries Research Center, Columbia River Research Laboratory, Cook, WA 98605.

${ }^{2}$ E-mail: ijezorek@usgs.gov
} 


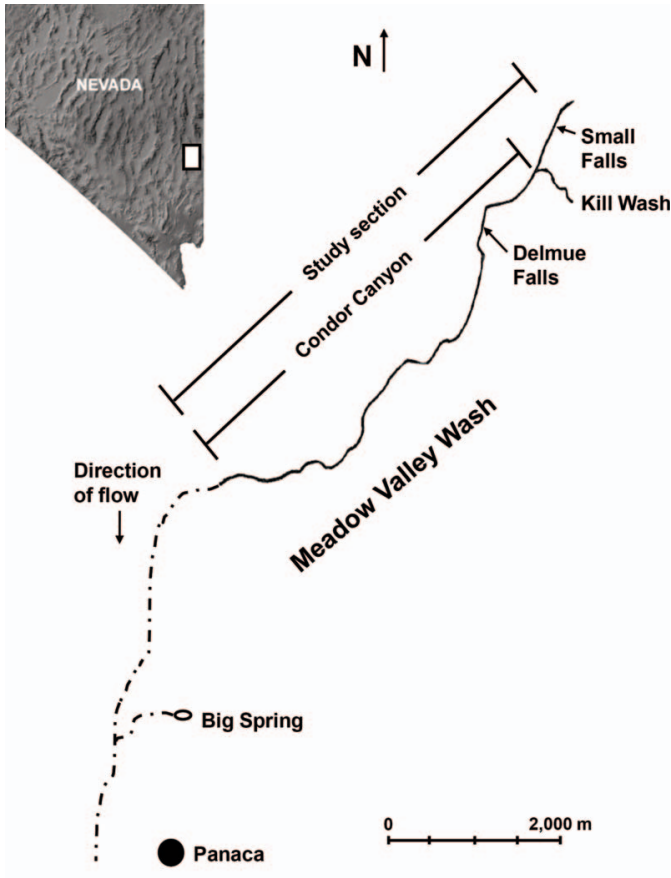

Fig. 1. Map of Meadow Valley Wash near Panaca, Nevada, showing the Condor Canyon section, the study area, and Big Spring, where Big Spring spinedace were originally found in the outflow stream in 1938. Downstream of Condor Canyon, Meadow Valley Wash was intermittent.

and stream habitats (Williams et al. 1989, Scoppettone et al. 2004b). Multiple populations of desert fish have gone extinct or have been extirpated from portions of their range (Miller et al. 1989, Williams et al. 1989). Habitat alteration, disruption of flow regimes, and introductions of nonnative species have all played a role in population reduction or extinctions. Among those species with documented declines are Little Colorado spinedace Lepidomeda vittata (Blinn et al. 1993, Tibbets et al. 2001, Sweetser et al. 2002), White River spinedace Lepidomeda albivallis (Scoppettone et al. 2004b), and Virgin River spinedace Lepidomeda mollispinis mollispinis (Cross 1985). One species of spinedace, Pahranagat spinedace Lepidomeda altivelis, is considered extinct (Miller et al. 1989).

Big Spring spinedace (Lepidomeda mollispinis pratensis) is a small cyprinid (maximum fork length $=115 \mathrm{~mm}$ ) of the Plagopterini tribe whose entire known population lies within an 8-km section of Meadow Valley Wash (MVW) near the town of Panaca,
Nevada (Figs. 1, 2) in the desert southwest of the United States. Big Spring spinedace were first documented in 1938, by Robert Miller and Carl Hubbs, in the outflow stream of Big Spring (also referred to as Panaca Spring), a tributary to MVW about $2 \mathrm{~km}$ downstream of the south end of Condor Canyon (Miller and Hubbs 1960). At the time, only 7 individuals were found. Surveys of Big Spring and MVW in 1959 (excluding Condor Canyon) failed to find any Big Spring spinedace, and they were believed extinct due to introduction of exotic species, water diversion, and habitat changes, including increased siltation and vegetation in the channel (Miller and Hubbs 1960). In 1977, a population of Big Spring spinedace was found in MVW just downstream of a large waterfall (Delmue Falls) in Condor Canyon (Allan 1983). Due to concerns about siltation occurring below Delmue falls (R.C. Allan, Nevada Department of Wildlife, unpublished data), the Nevada Department of Wildlife transplanted some larval Big Spring spinedace to sites about $1.5 \mathrm{~km}$ upstream of Delmue Falls in 1980. Mature Big Spring spinedace were found upstream of Delmue Falls during surveys in 1981 (R.C. Allan, Nevada Department of Wildlife, unpublished data). It is not known whether Big Spring spinedace were present upstream of the falls prior to 1980 or whether the transported fish simply matured.

Although the historical range of Big Spring spinedace is unknown, it is assumed that their range and populations have declined. They are no longer found at Big Spring, where they were originally documented by Miller and Hubbs (1960). The closest point to Big Spring where they have recently been found is about $5 \mathrm{~km}$ upstream in MVW (Figs. 1, 2). Because their range is restricted to one isolated section of stream, Big Spring spinedace are at risk from chronic or acute local disturbance. Natural or anthropogenic disturbances to MVW or effects of nonnative species could be detrimental to the population of Big Spring spinedace.

Because of the perceived vulnerability of this single isolated population, Big Spring spinedace were listed as threatened under the Endangered Species Act in 1985 (Federal Register 1985). This listing identified critical habitat for the Big Spring spinedace as MVW within Condor Canyon. The listed critical habitat did not extend upstream of Condor Canyon 


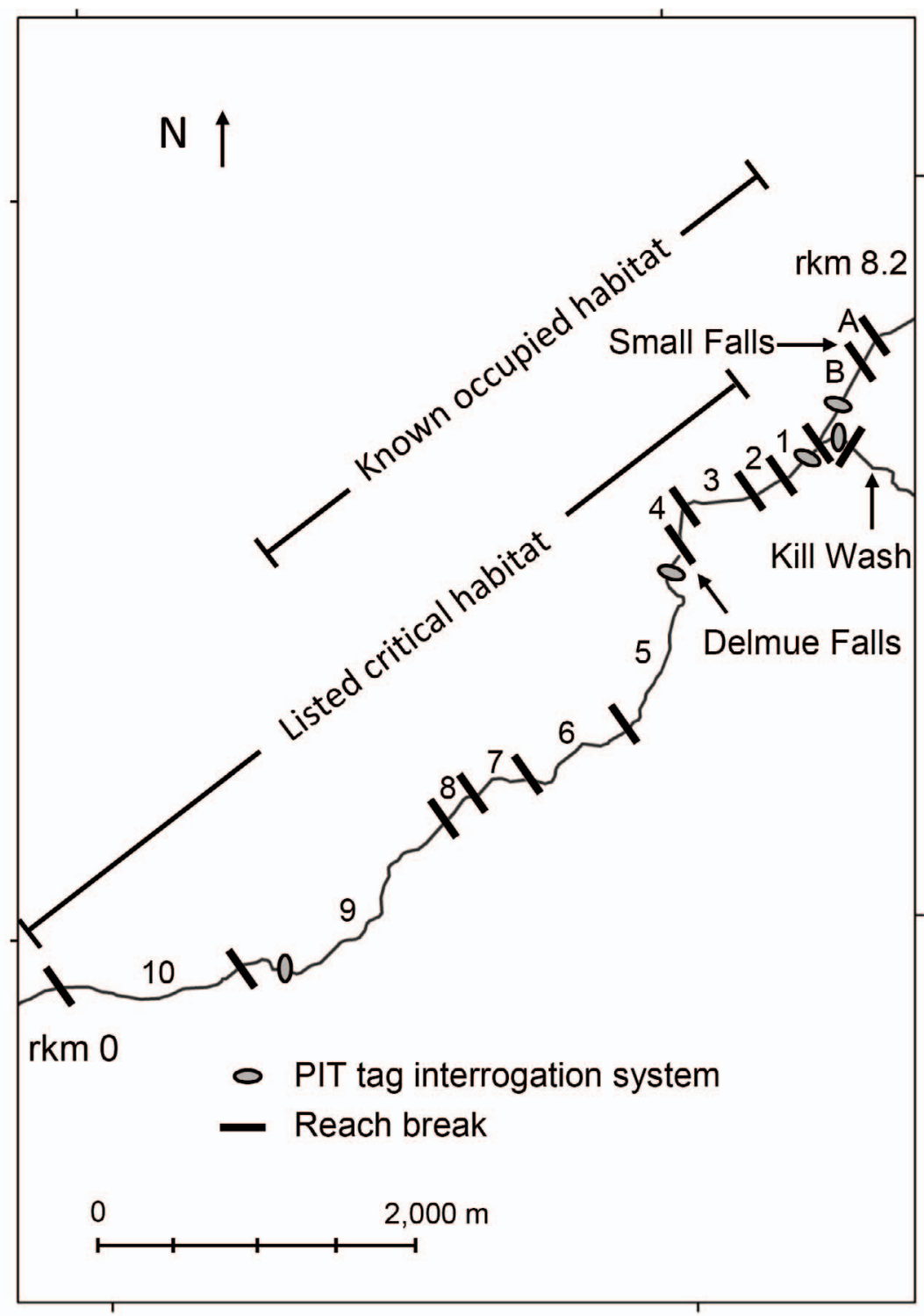

Fig. 2. Map of the Condor Canyon section of Meadow Valley Wash, Nevada, showing designated Big Spring spinedace critical habitat, reach breaks, passive integrated transponder (PIT) tag interrogation systems, and the habitat occupied by Big Spring spinedace, which included the tributary Kill Wash.

and did not include Kill Wash, a small springfed tributary at the upstream end of Condor Canyon. Managers with the Bureau of Land Management (BLM), U.S. Fish and Wildlife Service, and Nevada Department of Wildlife (NDOW) began to discuss potential actions to reduce risks to Big Spring spinedace. These actions included possible habitat restoration in Condor Canyon, securing instream water rights, and translocation of some Big Spring spinedace to other streams in an attempt to establish a buffer population (USFWS 1993).

Little is known about the habits and life history of Big Spring spinedace. Field observations of Big Spring spinedace indicate a spring spawning period. It is unknown whether individual Big Spring spinedace migrate, use Kill Wash, move downstream over the 2 waterfalls, or migrate downstream and out of the Condor Canyon section of MVW. Additionally, 
it is unknown whether size or condition of fish influences movement. Other spinedace species are known to move hundreds of meters or more. Sweetser et al. (2002) found that individual Little Colorado spinedace could move up to $1.5 \mathrm{~km}$, though movement was not common. A relocated population of White River spinedace expanded over 3 years to inhabit $700 \mathrm{~m}$ of stream in the Sunnyside Creek system of Nevada, though individual fish were not tracked (Scoppettone et al. 2004a).

Passive integrated transponder (PIT) tags offer a definitive way to track movement of individual fish (Ombredane et al. 1998, Connolly et al. 2008). Fish can be rapidly tagged, and the small size of the tags (as small as 8.5 $\mathrm{mm}$ long) allow tagging of fish as small as 60 mm (Baras et al. 2000, Carlson and Letcher 2003, Ruetz et al. 2006), including cyprinids. Ward et al. (2008) PIT-tagged juvenile bonytail chub Gila elegans and Gila chub Gila intermedia in the abdominal cavity and found tag retention $>97 \%$ and survival $>98 \%$ for both species after 30 days. In a study of PIT-tagged roach Rutilus rutilus and rudd Scardinius erythrophthalmus, Skov et al. (2005) found tag retention of $100 \%$ and survival $\geq 94 \%$ after 37 days. They found that fish whose incisions were not sutured recovered faster, had lower rates of infection, and survived at higher rates than those with sutured incisions (Skov et al. 2005). Because PIT tags have no battery, their effective life is not limited by battery-power constraints. However, detection of a PIT tag requires that it pass near an antenna (5-100 $\mathrm{cm}$ depending on tag size and antenna size and power). Antennas can be held to scan fish in-hand, attached to backpack-mounted transceivers for mobile scanning, or deployed in stationary locations where PIT-tagged fish can be detected if they pass within the antenna field.

Stationary PIT-tag interrogation systems (PTISs) have increasingly been used to document movement of PIT-tagged fish in streams (Armstrong et al. 1996, Zydlewski et al. 2001, 2006, Connolly et al. 2008). These systems offer a less labor-intensive method of detecting tagged fish than operating traps or weirs, which require much personnel time, and are less prone to damage or compromised effectiveness from flooding and debris.

To investigate Big Spring spinedace in MVW, we used electrofishing, PIT-tagging, and instream PTISs. The objectives of our study were to (1) assess distribution of Big Spring spinedace within a section of MVW; (2) assess movements of PIT-tagged Big Spring spinedace throughout the stream, particularly whether they used Kill Wash, were moving downstream over either of 2 falls, or moving through the lower portion of the study section where they have not been documented; and (3) determine whether size (FL = fork length) or condition at time of tagging differed between Big Spring spinedace that moved from their release site and those that were not detected moving from their release site.

\section{Methods \\ Study Area}

Our study section included $8.2 \mathrm{~km}$ of MVW, Nevada, primarily within Condor Canyon, but also included a small spring-fed tributary, Kill Wash, and a portion of MVW upstream of the confines of the canyon (Fig. 1). Condor Canyon is a rugged, steep-walled canyon located northeast of the town of Panaca, Lincoln County, Nevada, in sagebrush steppe. Our study section began at the downstream end of the canyon (Fig. $2 ; 37^{\circ} 49.830^{\prime},-114^{\circ} 22.629^{\prime}$, referenced as river $\mathrm{km} 0$;) and ended upstream of the canyon $\left(37^{\circ} 51.962^{\prime},-114^{\circ} 19.126^{\prime}\right.$, referenced as river $\mathrm{km}$ 8.2). Kill Wash enters MVW from the east at river $\mathrm{km}$ 7.4. Upstream of Kill Wash, MVW is no longer within the canyon, but flows through a landscape of pasture to the west and rolling hills to the east.

Average wetted width in our study section of MVW is about $3.0 \mathrm{~m}$ (Table 1) during typical flows, which vary from about 0.02 to 0.06 $\mathrm{m}^{3} \cdot \mathrm{s}^{-1}$. Much higher flows can occur during large storms. A flow of $26.9 \mathrm{~m}^{3} \cdot \mathrm{s}^{-1}$ was recorded in MVW $15 \mathrm{~km}$ upstream of Condor Canyon on 11 January 2005. Average wetted width in Kill Wash is about $1.3 \mathrm{~m}$ during typical flows, which vary from about 0.003 to $0.006 \mathrm{~m}^{3} \cdot \mathrm{s}^{-1}$. Several springs contribute water to MVW near the Kill Wash confluence. These springs are thought to contribute about $0.01 \mathrm{~m}^{3} \cdot \mathrm{s}^{-1}$ (USFWS 1993). Water temperatures have been recorded from -0.9 to $27.5^{\circ} \mathrm{C}$ in MVW and from 13.0 to $18.5^{\circ} \mathrm{C}$ in Kill Wash (Jezorek et al. 2011). Maximum temperatures occur in July or August, minimums in January and February. Substrate size varies from clay to boulder, with sand and silt dominant. 
TABLE 1. Descriptive habitat data for reaches in Meadow Valley Wash, Nevada, and Kill Wash, a tributary. Reaches are listed from upstream to downstream. Reaches A, B, and Kill Wash are immediately upstream of Condor Canyon; all other reaches are in the canyon. Substrate types are F, fines (clay/silt/sand); G, gravel; C, cobble; B, boulder; and O, other (woody debris, fine organic matter, vegetation). Table adapted from Jezorek et al. (2011).

\begin{tabular}{|c|c|c|c|c|c|c|c|c|c|c|}
\hline \multirow[b]{2}{*}{ Location } & \multirow{2}{*}{$\begin{array}{l}\text { Length } \\
(\mathrm{m})\end{array}$} & \multirow{2}{*}{$\begin{array}{l}\text { Mean } \\
\text { gradient } \\
(\%)\end{array}$} & \multirow{2}{*}{$\begin{array}{l}\text { Mean wetted } \\
\text { width } \\
(\mathrm{m})\end{array}$} & \multirow{2}{*}{$\begin{array}{c}\text { Mean } \\
\text { width:depth }\end{array}$} & \multirow{2}{*}{$\begin{array}{l}\text { Pools per } \\
100 \mathrm{~m}\end{array}$} & \multicolumn{5}{|c|}{ \% Substrate type } \\
\hline & & & & & & $\mathrm{F}$ & $\mathrm{G}$ & $\mathrm{C}$ & B & $\mathrm{O}$ \\
\hline Reach A & 178 & 0.4 & 2.3 & 16 & 1.1 & 53 & 27 & 10 & 10 & 0 \\
\hline Reach B & 567 & 0.3 & 2.8 & 35 & 1.1 & 73 & 18 & 0 & 4 & 4 \\
\hline Kill Wash & 94 & 0.2 & 1.3 & 100 & 2.1 & 17 & 83 & 0 & 0 & 0 \\
\hline Reach 1 & 335 & 0.1 & 2.6 & 34 & 1.8 & 39 & 35 & 20 & 6 & 0 \\
\hline Reach 2 & 231 & $<0.1$ & 2.3 & 19 & 2.6 & 52 & 46 & 3 & 0 & 0 \\
\hline Reach 3 & 480 & 0.1 & 2.5 & 23 & 0.6 & 76 & 24 & 0 & 0 & 0 \\
\hline Reach 4 & 280 & 0.5 & 3.7 & 39 & 1.1 & 84 & 4 & 0 & 2 & 9 \\
\hline Reach 5 & 1369 & 0.6 & 3.1 & 25 & 1.2 & 75 & 16 & 5 & 1 & 4 \\
\hline Reach 6 & 800 & 0.3 & 2.5 & 30 & 0.9 & 61 & 23 & 9 & 1 & 6 \\
\hline Reach 7 & 400 & 0.5 & 3.6 & 34 & 0.8 & 62 & 17 & 5 & 2 & 15 \\
\hline Reach 8 & 260 & 1.0 & 3.4 & 37 & 1.2 & 88 & 10 & 2 & 0 & 0 \\
\hline Reach 9 & 2020 & 0.8 & 3.0 & 28 & 3.1 & 74 & 8 & 2 & 1 & 15 \\
\hline Reach 10 & 1240 & 0.9 & 2.8 & 44 & 0.3 & 87 & 5 & 0 & 6 & 2 \\
\hline
\end{tabular}

Common aquatic vegetation types are cattail Typha sp., bulrush Scirpus sp., and watercress Nasturtium sp. Common riparian vegetation types are grasses, sedges Carex sp., coyote willow Salix exigua, black willow Salix gooddingii, and tamarisk Tamarix ramosissima (PBS\&J 2007, Jezorek et al. 2011).

Cattle and sheep graze within the study area, both in the canyon and on irrigated fields at the north end of the study area. Irrigation of agricultural land occurs upstream of the study area. Two reservoirs, which provide irrigation water, are located about $5 \mathrm{~km}$ and $15 \mathrm{~km}$ upstream of our study section. Pool area of the 2 reservoirs is about $0.24 \mathrm{~km}^{2}$ each. An abandoned railroad grade runs through the study section. The grade confines the stream, resulting in channelization and incision in some areas (U.S. Fish and Wildlife Service 1993, PBS\&J 2007).

The study section is divided into 13 reaches (12 mainstem reaches and Kill Wash; Fig. 2, Table 1). Reaches A and B are upstream of the confluence with Kill Wash and the confines of Condor Canyon. The reach break (at river $\mathrm{km}$ 7.9) between Reaches A and B is a small falls, which is about $2 \mathrm{~m}$ high with several distinct ledges. This falls is likely a barrier to upstream movement of Big Spring spinedace at most flows, based on jumping ability of similar stream-dwelling fish (Kondratieff and Myrick 2006, Mueller et al. 2008, Meixler et al. 2009). Downstream of Kill Wash, reaches 1-10 (from upstream to downstream) were demarked during a 2006 geomorphic assessment of Condor
Canyon. At that time, reach breaks were determined based on channel differences in entrenchment, gradient, sinuosity, and bank stability (PBS\&J 2007, Jezorek et al. 2011). Delmue Falls, a $12 \mathrm{~m}$ high falls located at river $\mathrm{km}$ 6.1 (Fig. 2) and the boundary between reaches 4 and 5 , is an obvious barrier to upstream fish movement due to its height and vertical drop. Delmue Falls is likely not natural, but rather the result of the railroad grade confining the stream, forcing it over a bedrock shelf, and causing incision (USFWS 1993, PBS\&J 2007).

Other native fish species in our study section are desert sucker Catostomus clarkii and speckled dace Rhinichthys osculus. A population of nonnative rainbow trout Oncorhynchus mykiss are found within the $2.0 \mathrm{~km}$ of stream downstream of Delmue Falls (Jezorek et al. 2011). Nonnative crayfish are common throughout the entire study section.

\section{Passive Integrated Transponder Tag Interrogation Systems}

We installed 5 single-antenna PTISs in October 2008 and operated them through December 2009. Each PTIS consisted of a Destron Fearing 2001F ISO Transceiver (Destron Fearing, St. Paul, MN), a $12-\mathrm{V}$ battery and solar panel for maintaining charge, and an in-stream antenna. The antenna wiring was housed in $7.6 \mathrm{~cm}$ diameter, schedule 80 PVC pipe configured in a rectangle $0.6 \mathrm{~m}$ high and 1.0-1.8 m long, depending on the stream width where deployed. The antennas were placed across the stream and were supported 


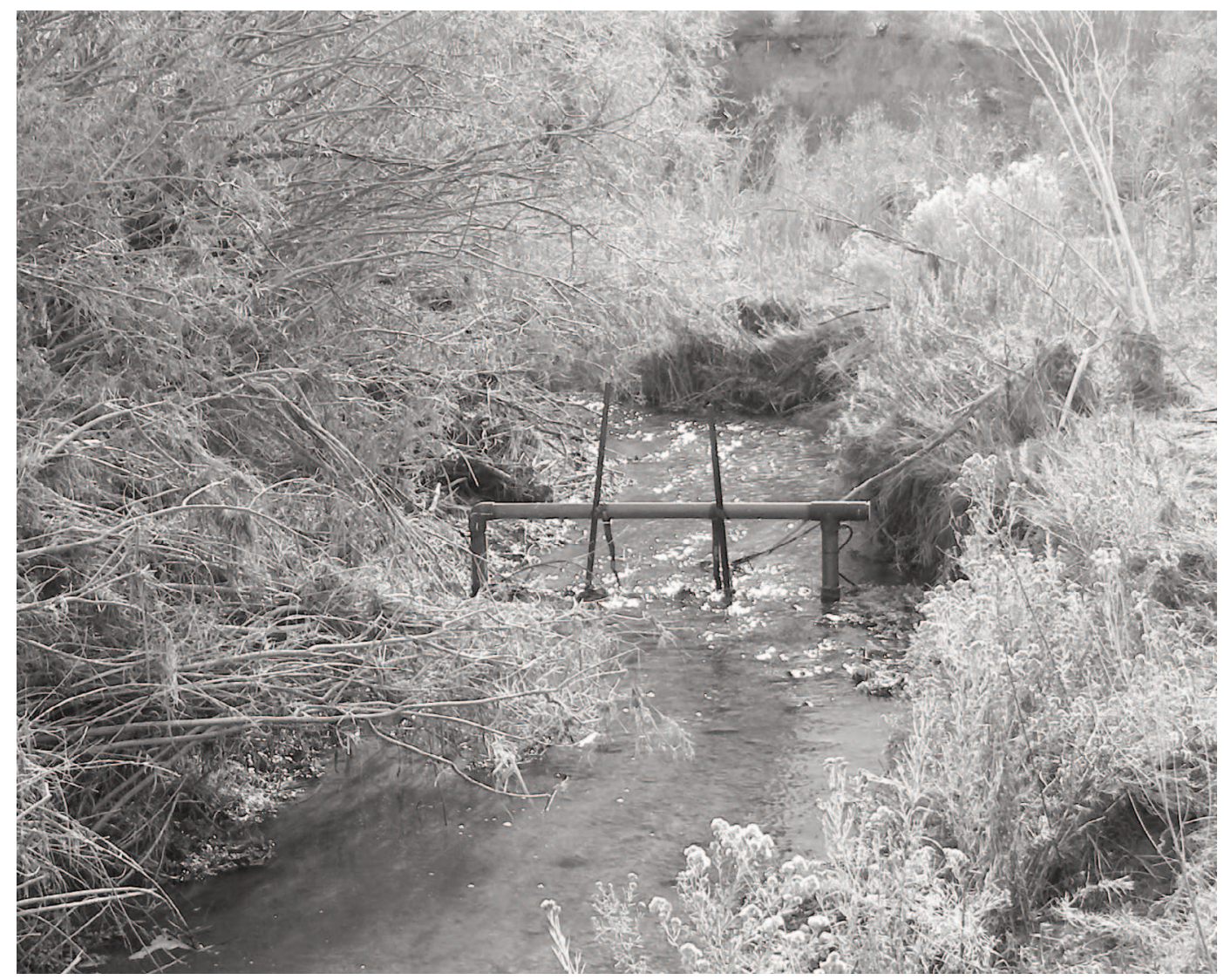

Fig. 3. The PIT-tag interrogation system antenna located in reach 1 of the Condor Canyon section of Meadow Valley Wash, Nevada. The antenna was $0.6 \mathrm{~m}$ high and $1.8 \mathrm{~m}$ long and supported upright by 2 fence posts. The transceiver, battery, and solar panel were on the right bank out of the photo.

upright by metal T-post fence posts as a window for fish to pass through (Fig. 3).

We installed 3 PTISs upstream of Delmue Falls (Fig. 2): one in reach B about $20 \mathrm{~m}$ upstream of the confluence with Kill Wash, one in Kill Wash about $10 \mathrm{~m}$ above the mouth, and one in reach 1 about $25 \mathrm{~m}$ downstream of the confluence with Kill Wash. These locations were selected to determine whether fish were moving from upstream or downstream areas to access Kill Wash and the confluence area with MVW.

We installed 2 PTISs downstream of Delmue Falls. One PTIS was placed in reach 5 (about $150 \mathrm{~m}$ downstream of Delmue falls; Fig. 2) to detect any PIT-tagged Big Spring spinedace that had gone downstream over the falls. The other PTIS was in reach 9, about $1.5 \mathrm{~km}$ below the most downstream point where we encountered Big Spring spinedace (Jezorek et al. 2011).
The PTIS in reach 9 was installed to determine whether PIT-tagged Big Spring spinedace were entering the lower part of the study area where they had not been documented.

The $8.5-\mathrm{mm}$ PIT tags that we used were detected by a PTIS if a tagged fish passed through the antenna window or within about $8 \mathrm{~cm}$ of the PVC pipe outside the window. The antennas were placed in narrow channel areas to minimize chances of missed detections. However, some circumstances could result in missed detections of PIT-tagged fish (Zydlewski et al. 2006, Bond et al. 2007). High flow could provide opportunity for fish to go around the antenna. Tag detection was influenced by orientation of the tag, with optimal orientation being perpendicular to the antenna. A PIT-tagged fish that passed in a lessthan-optimal orientation may not have been detected. A PIT tag in the antenna detection 
field could block another tag (Axel et al. 2005); thus, if a PIT-tagged fish was in the field and a second tagged fish entered the field, the second fish may not have been detected.

Personnel visited the PTISs weekly, downloaded data, replaced batteries if needed, and ran a test tag through the antenna window to confirm that each unit was functioning properly. Inadequate solar charging or interruption of charge due to solar equipment damage by grazing cattle occasionally resulted in lost power. We lost power on 5 days at the reach B PTIS, 4 days at the Kill Wash PTIS, 3 days at the reach 1 PTIS, 5 days at the reach 5 PTIS, and 7 days at the reach 9 PTIS. Our study was not designed to evaluate the reading efficiency of the PTISs. Constraints of one-antenna PTISs, limited numbers of tagged fish, and downtime precluded determining PTIS detection efficiencies.

When a PIT-tagged fish was detected at an antenna, the time and date of detection were saved to a file on the transceiver. Detections indicated that a PIT-tagged Big Spring spinedace was present at a PTIS antenna, but it may or may not have passed the antenna location. A fish detection at a PTIS was considered a movement when the PTIS was more than $25 \mathrm{~m}$ from the release site for that fish.

\section{Fish Collection and PIT-Tagging}

We electrofished in each reach (A, B, Kill Wash, 1-10) during 1-22 October 2008 and 12-18 March 2009 to assess distribution of Big Spring spinedace and to PIT-tag individuals. Electrofishing sections were $25 \mathrm{~m}$ long. Each reach had from 1 to 3 electrofishing sections (Jezorek et al. 2011). Electrofishing sections were netted off at either end prior to sampling. We used a Smith-Root LR-24 backpack electrofisher set to 160 volts at 30-60 Hertz. All water within the 25-m section was sampled. Captured fish were anesthetized in a minimal dose of MS-222, measured for fork length (FL) to the nearest $\mathrm{mm}$, and weighed to the nearest $0.1 \mathrm{~g}$.

We PIT-tagged Big Spring spinedace that were $70 \mathrm{~mm}(\mathrm{FL})$ or larger (PIT tags were 8.5 mm long, $134.2 \mathrm{kHz}$, full duplex). The $70-\mathrm{mm}$ minimum FL limit was a condition of our sampling permit. We used a surgical scalpel to create a $2-\mathrm{mm}$ incision on the right side of the midventral line about $2 \mathrm{~mm}$ posterior of the tip of the pectoral fin (Gries and Letcher 2002).
The tag was inserted into the incision, with the long axis of the tag parallel to the long axis of the fish. No sutures were used to close incisions. All instruments and tags were sterilized in $70 \%$ ethyl alcohol, as outlined by the Columbia Basin Fish and Wildlife Authority (1999). Once tagged, fish were scanned with a Digital Angel 2001F-ISO transceiver to record the tag code. We held fish in ambient-temperature stream water until they had recovered, then released them within the 25-m electrofishing section from which they were collected.

During sampling in March 2009 and during additional efforts in June 2009 and October 2009, we scanned Big Spring spinedace to determine whether they were previously PIT tagged. This scanning provided us another method of determining movement. If a PITtagged Big Spring spinedace was recaptured in a 25-m electrofishing site different from the one where it had been released, this was considered a movement.

\section{Length and Condition Factor Analysis}

We investigated whether fork length or Fulton's $\mathrm{K}$ at time of tagging differed between Big Spring spinedace that moved and those not detected moving (Wilcoxon-Mann-Whitney test: $P<0.05)$.

Fulton's $\mathrm{K}$ is calculated as follows:

$$
\mathrm{K}=\frac{\mathrm{W}}{\mathrm{FL}^{3}} 100,000,
$$

where $\mathrm{W}=$ weight $(\mathrm{g})$ and $\mathrm{FL}=$ fork length (mm).

We grouped fish by time of tagging (October 2008: $n=62$ tagged fish; March 2009: $n=$ 54 tagged fish) because fish tagged during October had more time to potentially move, and $\mathrm{K}$ differed substantially between the October and March groups. We limited our analysis of FL and $\mathrm{K}$ to fish PIT-tagged in reach B, Kill Wash, and reaches 1-4. We did not include fish tagged in reach A (October 2008: $n=22$; March 2009: $n=9$ ) because they were upstream of the small falls, and we did not have a detector there to document possible upstream movement. We considered Big Spring spinedace PIT-tagged below Delmue Falls (October 2008: $n=14$; March 2009: $n=40$ ) as a separate population because Delmue Falls was a barrier to upstream movement. We lacked adequate movement data for PIT-tagged Big Spring spinedace 
TABLE 2. Number of Big Spring spinedace (BSS) tagged with PIT tags and released by reach in Meadow Valley Wash, Nevada, and the number and percentage detected moving from their release location by PIT-tag interrogation systems (PTISs), and the percentage that moved to each of 5 PTISs. The PTISs were operated from October 2008 through December 2009. Fish tagged in reaches 5-7 were blocked from upstream passage by Delmue Falls, a $12 \mathrm{~m}$ high waterfall.

\begin{tabular}{|c|c|c|c|c|c|c|c|c|}
\hline \multirow[b]{2}{*}{$\begin{array}{l}\text { Reach of } \\
\text { capture and } \\
\text { release }\end{array}$} & \multirow[b]{2}{*}{$\begin{array}{l}\text { Date of } \\
\text { sample and } \\
\text { release }\end{array}$} & \multirow[b]{2}{*}{$\begin{array}{l}\text { Number of } \\
\text { BSS PIT- } \\
\text { tagged }\end{array}$} & \multirow[b]{2}{*}{$\begin{array}{c}\text { Number } \\
\text { detected } \\
\text { moving }\end{array}$} & \multicolumn{5}{|c|}{$\begin{array}{c}\text { Percentage of tagged BSS that were detected } \\
\text { moving to each PTIS site }\end{array}$} \\
\hline & & & & $\begin{array}{l}\text { Reach B } \\
\text { PTIS }\end{array}$ & $\begin{array}{c}\text { Kill } \\
\text { Wash } \\
\text { PTIS }\end{array}$ & $\begin{array}{l}\text { Reach } 1 \\
\text { PTIS }\end{array}$ & $\begin{array}{l}\text { Reach } 5 \\
\text { PTIS }\end{array}$ & $\begin{array}{l}\text { Reach } 9 \\
\text { PTIS }\end{array}$ \\
\hline \multirow[t]{2}{*}{ Reach A } & Oct 2008 & 22 & $0(0 \%)$ & 0 & 0 & 0 & 0 & 0 \\
\hline & Mar 2009 & 9 & $0(0 \%)$ & 0 & 0 & 0 & 0 & 0 \\
\hline \multirow{2}{*}{ Reach B } & Oct 2008 & 9 & $1(11 \%)$ & 0 & 11 & 0 & 0 & 0 \\
\hline & Mar 2009 & 2 & $1(50 \%)$ & 0 & 50 & 0 & 0 & 0 \\
\hline \multirow[t]{2}{*}{ Kill Wash } & Oct 2008 & 1 & $1(100 \%)$ & 0 & 0 & 100 & 0 & 0 \\
\hline & Mar 2009 & 0 & 1 & 0 & 0 & 0 & 0 & 0 \\
\hline \multirow{2}{*}{ Reach 1} & Oct 2008 & 11 & $4(27 \%)$ & 0 & 27 & 27 & 0 & 0 \\
\hline & Mar 2009 & 12 & $5(42 \%)$ & 0 & 25 & 25 & 0 & 0 \\
\hline \multirow{2}{*}{ Reach 2} & Oct 2008 & 6 & $3(50 \%)$ & 17 & 17 & 33 & 0 & 0 \\
\hline & Mar 2009 & 15 & $3(20 \%)$ & 0 & 0 & 20 & 0 & 0 \\
\hline \multirow[t]{2}{*}{ Reach 3} & Oct 2008 & 29 & $10(34 \%)$ & 3 & 24 & 34 & 0 & 0 \\
\hline & Mar 2009 & 18 & $8(44 \%)$ & 0 & 11 & 33 & 6 & 0 \\
\hline \multirow{2}{*}{ Reach 4} & Oct 2008 & 8 & $3(38 \%)$ & 0 & 25 & 38 & 0 & 0 \\
\hline & Mar 2009 & 7 & $3(43 \%)$ & 0 & 29 & 29 & 0 & 0 \\
\hline \multirow[t]{2}{*}{ Reach 5} & Oct 2008 & 1 & $1(100 \%)$ & - & - & - & 100 & 0 \\
\hline & Mar 2009 & 0 & $0(0 \%)$ & - & - & - & 0 & 0 \\
\hline \multirow[t]{2}{*}{ Reach 6} & Oct. 2008 & 9 & $0(0 \%)$ & - & - & - & 0 & 0 \\
\hline & Mar 2009 & 36 & $2(6 \%)$ & - & - & - & 6 & 0 \\
\hline \multirow[t]{2}{*}{ Reach 7} & Oct. 2008 & 4 & $1(25 \%)$ & - & - & - & 25 & 0 \\
\hline & Mar 2009 & 4 & $0(0 \%)$ & - & - & - & 0 & 0 \\
\hline Totals & & 203 & $46(23 \%)$ & & & & & \\
\hline
\end{tabular}

downstream of Delmue Falls to analyze differences at time of tagging between those fish that moved (October 2008: $n=2$; March 2009: $n=2)$ and those not detected moving (October 2008: $n=12$; March 2009: $n=38$ ).

\section{Thermologgers}

We deployed thermologgers (Onset Hobo Water Temp Pro v2, Onset Computer Corp., Bourne, MA) within the study section to determine thermal differences, particularly in Kill Wash and the nearby area of spring influence in MVW. Thermologgers were located in Reach B about $25 \mathrm{~m}$ upstream of Kill Wash, in Kill Wash, in reach 1 about $50 \mathrm{~m}$ downstream of Kill Wash, in reach 2 , in reach 5 immediately below Delmue Falls, and at the downstream end of reach 9 . Water temperatures were recorded once per hour at each thermologger from November 2008 through December 2009.

\section{RESUlTS}

\section{Distribution and PIT-Tagging}

Big Spring spinedace were present in all 6 mainstem reaches upstream of Delmue Falls and in Kill Wash (26-115 mm FL). Downstream of Delmue Falls, Big Spring spinedace were present in reaches $5,6,7$, and 8 (44-115 $\mathrm{mm}$ FL). We did not capture any Big Spring spinedace in reaches 9 or 10, despite electrofishing two 25-m sections in each reach in October 2008, one section in reach 9 in March 2009 , one section in reach 9 in October 2009, and 2 sections in reach 10 in October 2009.

We PIT-tagged 203 Big Spring spinedace during sampling in October $2008(n=100)$ and March 2009 ( $n=103)$. Big Spring spinedace were PIT-tagged in each of the reaches where found (Table 2), except reach 8, where none captured were large enough to PIT-tag $(n=11,55-64 \mathrm{~mm}$ FL). In addition to the 203 Big Spring spinedace that we PIT-tagged during October 2008 and March 2009, we captured 592 individuals $<70 \mathrm{~mm}$ FL and 135 individuals $\geq 70 \mathrm{~mm}$ FL that we did not PITtag (permit limitations prevented us from PITtagging additional fish). During electrofishing sampling in June and October 2009 (when we did not PIT-tag Big Spring spinedace), we captured 529 individuals $<70 \mathrm{~mm}$ FL and 213 individuals $\geq 70 \mathrm{~mm}$ FL. These numbers are 


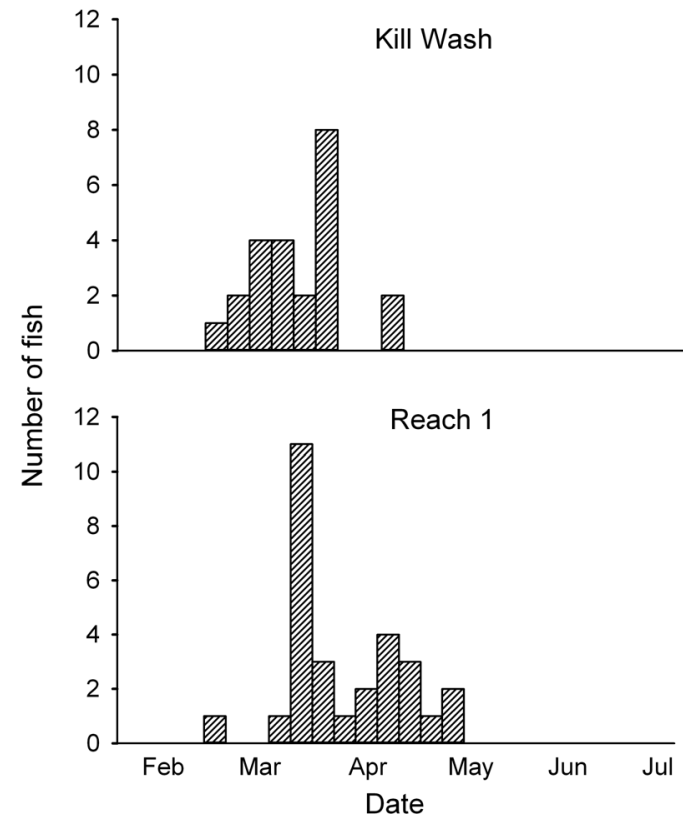

Fig. 4. First detection, by date, of Big Spring spinedace that moved from their tagging location and were detected by PIT-tag interrogation systems in Kill Wash and reach 1 of the Condor Canyon section of Meadow Valley Wash, Nevada, from November 2008 through December 2009. A total of 41 fish were detected on these 2 readers. Two of these fish had moved downstream from their release location, and 39 had moved upstream from their release location.

reported for reference and are not an index of Big Spring spinedace population. We recaptured 58 of the 203 PIT-tagged Big Spring spinedace during sampling in March, June, and October 2009. We found a ripe female Big Spring spinedace $(\mathrm{FL}=71 \mathrm{~mm})$ in reach 3 on 22 June 2009.

\section{Movement}

Of the 203 PIT-tagged Big Spring spinedace, we documented 47 individuals that moved more than $25 \mathrm{~m}$ from their release site (46 by detection at PTISs, 1 by electrofishing recapture). Big Spring spinedace moved into Kill Wash from all reaches above Delmue Falls except from reach A (Table 2). None of the 31 Big Spring spinedace that we PIT-tagged above the small falls in reach A were detected at our PTISs downstream. Two of the 11 Big Spring spinedace tagged in reach B were detected moving downstream and into Kill Wash, but none were detected moving downstream of the Kill Wash confluence into reach
1. Thirty-nine of the 106 Big Spring spinedace that we PIT-tagged and released in reaches 1-4 were detected moving upstream to the reach 1 or Kill Wash PTISs (33 individuals at the reach 1 PTIS, 22 individuals at the Kill Wash PTIS). Only 2 of the 106 were detected moving upstream to the PTIS in reach B (upstream of Kill Wash). We PIT-tagged and released only one Big Spring spinedace in Kill Wash (in October 2008), and it was later detected downstream in reach 1 .

A Big Spring spinedace that was PITtagged upstream of Delmue Falls in reach 3 was detected below Delmue Falls at our PTIS in reach 5. This fish may have moved downstream and over the falls; however, we cannot rule out the possibility of mortality, with the carcass washing downstream or being eaten by a predator that was then detected.

The one Big Spring spinedace PIT-tagged in reach 5 was detected moving upstream to the reach 5 PTIS. Two of 45 Big Spring spinedace tagged in reach 6 , and 1 of 8 tagged in reach 7 , were detected moving upstream to the reach 5 PTIS. An additional PIT-tagged Big Spring spinedace from reach 7 moved upstream to reach 6 (documented through electrofishing recapture). Big Spring spinedace from Reaches 6 and 7 may have made substantial movements that went undetected because there were no PTISs in those reaches. We did not detect any PIT-tagged Big Spring spinedace at the mostdownstream PTIS, located in reach 9.

Forty-five individual PIT-tagged Big Spring spinedace were detected moving from their release location between early March and late May 2009. Initial detections of individuals at the reach 1 PTIS peaked in early April, followed by a peak in Kill Wash in mid-April (Fig. 4). A second peak of initial detections occurred at the reach 1 PTIS in May. Individual fish that moved to the reach 1 or Kill Wash PTISs had from 1 to 87 detection records each. Fish that had 2 or more detection records, spent from 1 to 67 days $(n=35, \bar{x}=18$, median $=3$ ) in the reach $1 /$ Kill Wash confluence area. The 2 fish from reach 6 and one fish from reach 7 were detected at the reach 5 PTIS between 1 May and 9 May 2009.

Three Big Spring spinedace were detected moving outside the spring 2009 period. Two of these detections occurred during the October 2008 electrofishing sampling. These two Big Spring spinedace may have been displaced by 
Table 3. Detection and recapture histories of 5 PIT-tagged Big Spring spinedace in Meadow Valley Wash, Nevada. Movement was documented by detection at instream PIT-tag interrogation systems (PTISs) and by electrofishing recaptures. Each fish moved upstream from its release location to detection at a PTIS, then moved downstream back to its release location (or very near in the case of fish 3).

\begin{tabular}{|c|c|c|c|c|c|}
\hline \multirow[b]{2}{*}{ Fish } & \multicolumn{4}{|c|}{ Location and date of contacts } & \multirow{2}{*}{$\begin{array}{l}\text { Distance to } \\
\text { farthest point } \\
\text { of contact }\end{array}$} \\
\hline & Release & Second contact & Third contact & Fourth contact & \\
\hline 1 & $\begin{array}{l}\text { Reach } 2, \\
21 \text { Oct } 08\end{array}$ & $\begin{array}{l}\text { PTIS, reach B, } \\
29 \text { Oct } 08\end{array}$ & $\begin{array}{l}\text { Recapture, reach } 2 \text {, } \\
15 \text { Mar } 08\end{array}$ & - & $500 \mathrm{~m}$ \\
\hline 2 & $\begin{array}{l}\text { Reach } 1, \\
\quad 1 \text { Oct } 08\end{array}$ & $\begin{array}{l}\text { Recapture, reach 1, } \\
\text { 13 Mar } 09\end{array}$ & $\begin{array}{l}\text { PTIS, Kill Wash, } \\
12 \text { Apr } 09\end{array}$ & $\begin{array}{l}\text { Recapture, reach } 1 \text {, } \\
24 \text { June } 09\end{array}$ & $50 \mathrm{~m}$ \\
\hline 3 & $\begin{array}{l}\text { Reach 3, } \\
\text { 15 Mar } 09\end{array}$ & $\begin{array}{l}\text { PTIS, reach } 1 \\
11 \text { Apr } 09\end{array}$ & $\begin{array}{l}\text { Recapture, reach } 4 \text {, } \\
24 \text { June } 09\end{array}$ & - & $800 \mathrm{~m}$ \\
\hline 4 & $\begin{array}{l}\text { Reach 2, } \\
\quad 15 \text { Mar } 09\end{array}$ & $\begin{array}{l}\text { PTIS, reach } 1 \text {, } \\
6 \text { Apr } 09\end{array}$ & $\begin{array}{l}\text { Recapture, reach } 2 \text {, } \\
24 \text { June } 09\end{array}$ & - & $450 \mathrm{~m}$ \\
\hline 5 & $\begin{array}{l}\text { Reach } 2, \\
\quad 21 \text { Oct } 08\end{array}$ & $\begin{array}{l}\text { PTIS, Kill Wash, } \\
11 \text { March } 09\end{array}$ & $\begin{array}{l}\text { Recapture, reach 2, } \\
\quad 15 \text { Mar } 09\end{array}$ & - & $500 \mathrm{~m}$ \\
\hline
\end{tabular}

the electrofishing disturbance. Both individuals moved into Kill Wash during spring 2009. The one other Big Spring spinedace that moved outside the spring 2009 period was detected in December (at the reach 5 PTIS).

We documented PIT-tagged Big Spring spinedace making substantial movements from their release sites. The longest movement we recorded was $2.1 \mathrm{~km}$. This movement entailed upstream travel from the release location in reach 7 to the reach 5 PTIS. Fifteen fish moved more than $1 \mathrm{~km}$ from their release location to a PTIS, and all of these moved upstream from their release site. The limitations of our PTIS placements did not allow us to determine whether all of these fish later returned downstream. However, we did find that Big Spring spinedace were capable of returning to their release site after substantial upstream movement.

We documented 5 Big Spring spinedace that moved upstream and later returned downstream to their release location (or very near). These return events were documented by recapturing the fish (with electrofishing efforts) subsequent to PIT-tagging and detection at PTISs (Table 3). These recaptured fish, albeit a small proportion of our total PITtagged population, suggest fidelity to site, with returns to the home reach after movement to points 50-800 $\mathrm{m}$ upstream of the release site.

\section{Length and Condition Factor Analysis}

Neither length nor condition at the time of tagging appeared to influence likelihood of movement of Big Spring spinedace. During October 2008, PIT-tagged Big Spring spinedace in reach B, Kill Wash, and reaches 1-4 ranged in FL from 70 to $103 \mathrm{~mm}(\bar{x}=79$, SD $=7.5$, median $=78)$ and ranged in condition factor from 0.84 to $1.33(\bar{x}=1.09, \mathrm{SD}=0.09$, median $=1.09)$. We found no significant difference in FL or condition factor at time of tagging in October 2008 (Fig. 5) between fish that moved from their release location and those not detected moving (detected moving: $n=$ 22; not detected: $n=40$; Wilcoxon's rank sums: FL, $Z=0.02, P>0.9$; condition, $Z=$ $1.8, P=0.06)$. During March 2009, PIT-tagged Big Spring spinedace in reach B, Kill Wash, and reaches 1-4 ranged in FL from 70 to 93 $\mathrm{mm}(\bar{x}=77, \mathrm{SD}=6.1$, median $=75)$ and ranged in condition factor from 1.07 to $1.63(\bar{x}$ $=1.34, \mathrm{SD}=0.12$, median $=1.35)$. We found no significant difference in FL or condition factor at time of tagging during March 2009 (Fig. 5) between fish that later moved from their release location and those not detected moving (detected moving: $n=19$; not detected: $n=35$; Wilcoxon's rank sums: FL, $Z=$ $0.34, P=0.7$; condition, $Z=0.00, P=1.0$ ).

\section{Thermologgers}

Our network of thermologgers recorded water temperatures from November 2008 through December 2009. Water temperature range during this time was $-0.9{ }^{\circ} \mathrm{C}$ to $26.4{ }^{\circ} \mathrm{C}$. Water temperatures in Kill Wash were generally more moderate than those in the mainstem MVW (Table 4). Water temperatures in Kill Wash were warmer during winter and early spring and cooler during late spring and summer. Within mainstem MVW, water temperatures were similarly moderated near the confluence with Kill Wash and the spring's inputs near that confluence (Table 4). 

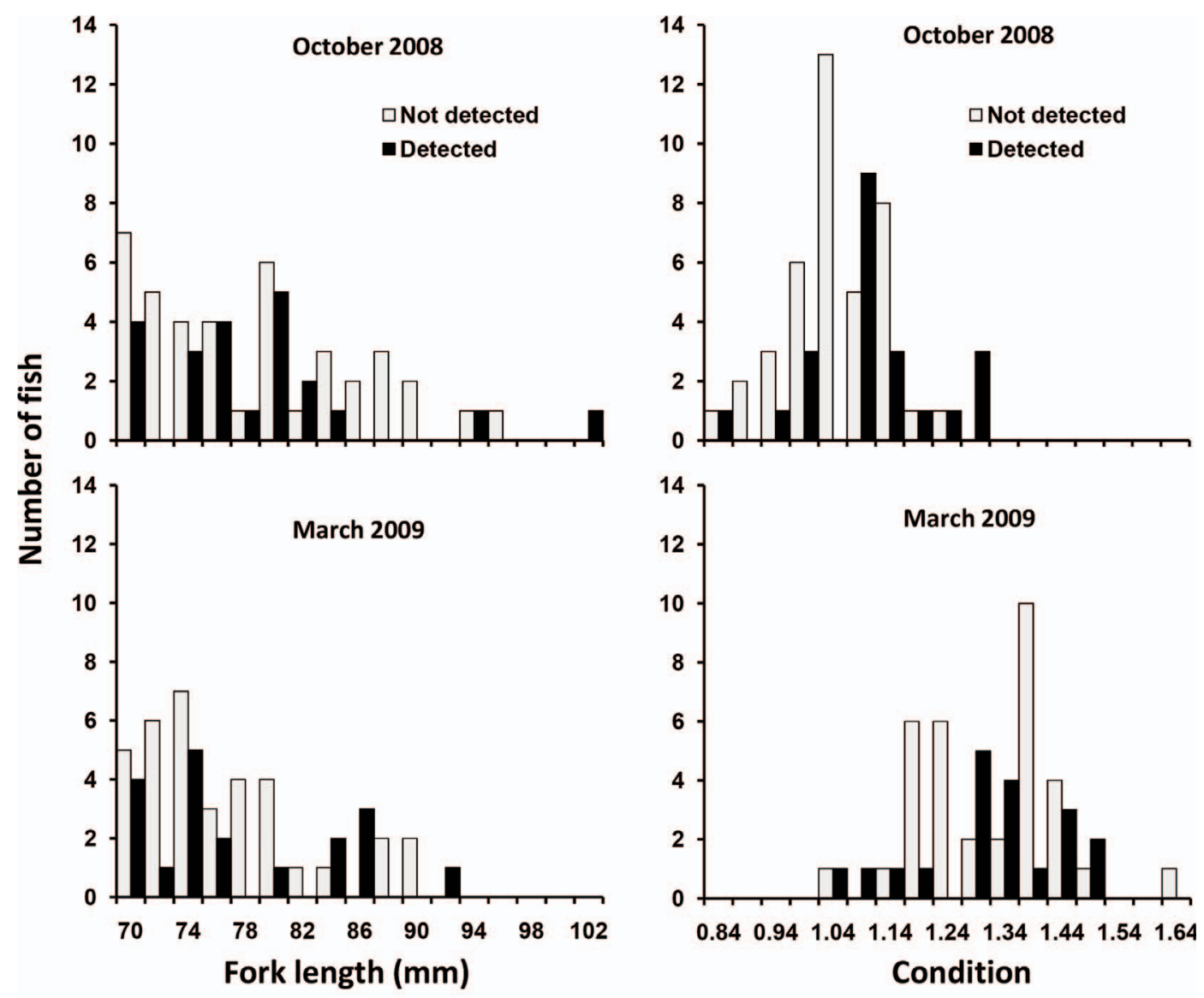

Fig. 5. Fork lengths and condition factor (weight in $\mathrm{g} \cdot \mathrm{FL}^{-3}$ in $\mathrm{mm} * 100,000$ ) of PIT-tagged Big Spring spinedace that subsequently moved from their release location (detected) and those that were not detected moving (not detected). Fish were tagged during October 2008 and March 2009 in areas of Meadow Valley Wash, Nevada, in and upstream of Condor Canyon.

TABle 4. Mean water temperatures $\left({ }^{\circ} \mathrm{C}\right)$ during March, April, and May 2009, and temperature range $\left({ }^{\circ} \mathrm{C}\right)$ during both March-May 2009 and the entire study period (November 2008-December 2009) at 5 thermologger sites in Meadow Valley Wash, Nevada, and Kill Wash, a tributary.

\begin{tabular}{llccccrr}
\hline & & & \multicolumn{3}{c}{ Mean temperature } & & Range: Mar- \\
Location & Latitude & Longitude & March & April & May & $\begin{array}{c}\text { Range: study } \\
\text { period }\end{array}$ \\
\cline { 5 - 6 } Reach B & $37^{\circ} 51.649^{\prime}$ & $-114^{\circ} 19.373^{\prime}$ & 11.1 & 12.9 & 16.6 & $6.1-22.9$ & $3.1-26.4$ \\
Kill Wash & $37^{\circ} 51.598^{\prime}$ & $-114^{\circ} 19.374^{\prime}$ & 14.8 & 15.3 & 16.1 & $13.8-17.5$ & $13.0-17.5$ \\
Reach 1 & $37^{\circ} 51.577^{\prime}$ & $-114^{\circ} 19.410^{\prime}$ & 12.1 & 13.8 & 16.7 & $7.9-21.5$ & $5.6-21.5$ \\
Reach 2 & $37^{\circ} 51.475^{\prime}$ & $-114^{\circ} 19.591^{\prime}$ & 11.9 & 13.4 & 16.8 & $7.9-24.6$ & $5.4-24.6$ \\
Reach 5 & $37^{\circ} 51.158^{\prime}$ & $-114^{\circ} 20.051^{\prime}$ & 9.9 & 12.2 & 16.3 & $4.4-22.1$ & $-0.1-22.5$ \\
Reach 9 & $37^{\circ} 49.909^{\prime}$ & $-114^{\circ} 21.849^{\prime}$ & 6.8 & 10.2 & 15.7 & $1.2-19.8$ & $-0.9-22.8$ \\
\hline
\end{tabular}

\section{Discussion}

We documented Big Spring spinedace throughout much of the Condor Canyon section of MVW, as well as upstream of the canyon and in Kill Wash. During spring 2009, Big Spring spinedace $\geq 70 \mathrm{~mm}$ FL moved to Kill Wash and the portion of MVW near its confluence (we detected movement of $36 \%$ of those tagged in reaches B and 1-4). Big 
Spring spinedace moved into these areas from both downstream and upstream of Kill Wash. No Big Spring spinedace were documented moving downstream over the smaller falls (river $\mathrm{km} \mathrm{7.9)}$ in the upper portion of our study area, and one fish was documented moving downstream over Delmue Falls (river $\mathrm{km} \mathrm{6.1)}$, suggesting that movement of fish $\geq 70 \mathrm{~mm}$ FL downstream over the 2 falls was uncommon. Movement of Big Spring spinedace was also documented between the reaches below Delmue Falls. Movement of Big Spring spinedace $\geq 70 \mathrm{~mm}$ FL did not appear to be influenced by fork length or condition factor at time of tagging for groups tagged in October 2008 or March 2009.

The current critical habitat for Big Spring spinedace includes MVW from the lower end of Condor Canyon to the upper end of the canyon. We found that Big Spring spinedace occupy Kill Wash and at least $0.8 \mathrm{~km}$ of MVW upstream of Kill Wash, areas which are not included in the current critical habitat listing. There was no apparent barrier to upstream movement of Big Spring spinedace at the upper end of our study section, and further surveys to determine the maximum upstream distribution of fish are warranted. Managers may wish to reevaluate the critical habitat designation to include Kill Wash and the $0.8 \mathrm{~km}$ of MVW upstream of Kill Wash.

The lower $3.3 \mathrm{~km}$ of MVW in Condor Canyon is listed as critical habitat, but we encountered no Big Spring spinedace there through electrofishing surveys or movement to a PTIS. This lower section of MVW in Condor Canyon has habitat conditions likely unfavorable to Big Spring spinedace. Habitat surveys reported by Jezorek et al. (2011) found a paucity of gravel substrates and high incidence of fine substrates in this section of stream. Additionally, they reported high density of cattail and bulrush in these lower reaches. Increased density of vegetation and fines was theorized to have contributed to the extirpation of Big Spring spinedace from their type locality (Miller and Hubbs 1960). Historically, Big Spring spinedace likely occupied or moved through the lower section of Condor Canyon. This assertion is based on their documented presence downstream of the canyon (Miller and Hubbs 1960) and later reports of their presence near Delmue Falls, well upstream of this lower canyon section
(Allan 1983). It appears that opportunities exist for restoration actions in the lower 3.3 $\mathrm{km}$ of MVW to improve conditions there and expand habitat for Big Spring spinedace.

Kill Wash and the section of MVW near its confluence appear to have an important role for populations of Big Spring spinedace. Extensive movements to these areas occurred nearly exclusively in spring. Though we cannot be certain of the reason for the spring movements, evidence suggests they are spawning related. University of Nevada personnel observed that 18 of 39 Big Spring spinedace collected in May 1990 exhibited spawning coloration or tuberculation on the head. Other spinedace species are known to spawn in spring (Blinn et al. 1998, Scoppetone et al. 2004a), and we captured a 71-mm gravid female Big Spring spinedace on 22 June 2009. However, definitive data on spawning timing and habitat requirements for Big Spring spinedace do not exist (USFWS 1993). Additional study is warranted to determine whether Big Spring spinedace are spawning in these areas and, if so, to determine their spawning habitat preferences.

Thermal differences or availability of food resources also may have influenced movement. During March and April, Big Spring spinedace may have moved to Kill Wash and the MVW confluence area with Kill Wash due to the warmer water temperatures found in those areas. Regardless of the reason for movement, habitat connectivity and heterogeneity of these areas are likely critical to persistence of the species.

Our data suggest that downstream movement over the 2 waterfalls in the study section was uncommon for Big Spring spinedace $\geq 70$ mm FL. Delmue Falls is a definitive barrier to upstream movement, and the small falls is likely a barrier. The prevalence of movements by Big Spring spinedace $<70 \mathrm{~mm}$ FL is unknown and bears investigation. The genetic implications of the partial separation of portions of the population and likely one-way flow of genes are unknown. Jezorek et al. (2011) collected genetic material from Big Spring spinedace throughout MVW, but these samples have yet to be analyzed.

We found no significant difference in FL or Fulton's $\mathrm{K}$ at time of tagging between fish that we detected moving and those we did not detect moving. Thus, movements of mature 
adult fish $(\geq 70 \mathrm{~mm}$ FL) in the PIT-tagged population are likely not due to displacement of smaller individuals by larger, dominant fish, nor is it only the largest fish that move. Fish that moved were likely seeking some habitat or resource condition that provided a benefit, such as spawning substrate, food resources, or preferred thermal conditions.

This study demonstrated that Big Spring spinedace $\geq 70 \mathrm{~mm}$ FL are capable of movement of $2 \mathrm{~km}$ or more, and that in MVW, movement was primarily during spring. Some of the Big Spring spinedace we detected moving later returned to their original tagging location, demonstrating site fidelity. Kill Wash and the area around its confluence with MVW appear seasonally important to adult Big Spring spinedace. Jezorek et al. (2011) found that the mainstem area around this confluence produced some of the highest population densities of Big Spring spinedace in MVW. Movements of Big Spring spinedace within MVW both above and below Delmue Falls demonstrated that adult Big Spring spinedace could move through stream sections with a moderate gradient and suggests that individual fish are capable of searching for preferred habitat conditions. Robust populations of Big Spring spinedace likely require sections of stream with connectivity to a diversity of habitats. These considerations are important should habitat restoration actions occur within MVW or fish translocations be attempted into habitat that may meet the requirements of the species.

\section{ACKNOWLEDGMENTS}

We thank Karen Prentice of the BLM, who was our funding officer. This study was conducted under U.S. Fish and Wildlife Service permit TE185631-0 and Nevada Department of Wildlife permit S 31312. Fellow USGS employees who spent many hours in the field and office were Brady Allen, Jodi Charrier, Katlyn Cox, Jessica Fischer, Teresa Fish, Bethany Grey, Anita Lahey, Kyle Martens, Carrie Munz, and Brien Rose. Tom Batt of the USGS provided help with the map figures. We received frequent field help from Sunny Sawyer, an associate of the Chicago Botanical Gardens stationed with BLM. Mark Beckstrand and Brian Hobbs of NDOW provided field help. Phil Cunningham, Shawn Goodchild, and Lee Simons from the U.S. Fish and Wildlife Service helped in the field and with permitting. We also thank the Delmue family for property access, without which this study would have been impossible. The use of trade, firm, or corporation names in this publication is for informational use and convenience of the reader. Such use does not constitute an official endorsement or approval by the United States Department of Interior or the U.S. Geological Survey of any product or service to the exclusion of others that may be suitable.

\section{Literature Cited}

Allan, R.C. 1983. Protected species range extension. Proceedings of the Desert Fishes Council, Volumes III-IX:319-321.

Armstrong, J.D., V.A. Braithwaite, and P. Rycroft. 1996. A flat-bed passive integrated transponder antenna array for monitoring behavior of Atlantic salmon parr and other fish. Journal of Fish Biology 48:539-541

Axel, G.A., E.F. Prentice, and B.P. Sandford. 2005. PIT-tag detection system for large-diameter juvenile fish bypass pipes at Columbia River basin hydroelectric dams. North American Journal of Fisheries Management 25:646-651.

Baras, E., C. Malbrouck, M. Houbart, P. Kestermont, and C. MELaRd. 2000. The effect of PIT tags on growth and physiology of age-0 cultured Eurasian perch Perca fluviatilis of variable size. Aquaculture 185:159-173.

Blinn, D.W., C. Runk, D.A. Clark, and J.N. Rinne. 1993. Effects of rainbow trout predation on Little Colorado spinedace. Transactions of the American Fisheries Society 122:139-143.

Blinn, D.W., J. White, T. Pradetto, and J. O'Brien. 1998. Reproductive ecology and growth of a captive population of Little Colorado spinedace (Lepidomeda vittata: Cyprinidae). Copeia 4:1010-1015.

Bond, M.H., C.V. Hanson, R. Baertsch, S.A. Hayes, and R.B. MacFarlane. 2007. A new low-cost instream antenna system for tracking passive integrated transponder (PIT)-tagged fish in small streams. Transactions of the American Fisheries Society 136: $562-566$.

Carlson, S.M., and B.H. Letcher. 2003. Variation in brook and brown trout survival within and among seasons, species, and age classes. Journal of Fish Biology 63:780-794.

Columbia Basin Fish and Wildlife Authority. 1999. PIT tag marking procedures manual. Columbia Basin Fish and Wildlife Authority, Portland, OR.

Connolly, P.J., I.G. JezoreK, K. Martens, and E.F. Prentice. 2008. Measuring performance of two stationary interrogation systems for detecting downstream and upstream movement of PIT-tagged salmonids. North American Journal of Fisheries Management 28:402-417.

Cross, J.N. 1985. Distribution of fish in the Virgin River, a tributary of the lower Colorado River. Environmental Biology of Fishes 12(1):13-21. 
Federal Register. 1985. Endangered and threatened wildlife and plants-Determination of threatened status and critical habitat for Big Spring spinedace. U.S. Fish and Wildlife Service 50(60):12298-12302.

Gries, G., AND B.H. Letcher. 2002. Tag retention and survival of age-0 Atlantic salmon following surgical implantation with passive integrated transponder tags. North American Journal of Fisheries Management 22:219-222.

Jezorek, I.G., P.J. Connolly, C.S. Munz, and C. Dixon. 2011. Big Spring spinedace and associated fish populations and habitat conditions in Condor Canyon, Meadow Valley Wash, Nevada. U.S. Geological Survey Open-File Report 2011-1072. 116 pp.

KondratiefF, M.C., And C.A. Myrick. 2006. How high can brook trout jump? A laboratory evaluation of brook trout jumping performance. Transactions of the American Fisheries Society 135:361-370.

Meixler, M.S., M.B. Bain, And M.T. Walter. 2009. Predicting barrier passage and habitat suitability for migratory fish species. Ecological Modelling 220: $2782-2791$.

Miller, R.R., And C.L. Hubbs. 1960. The spiny-rayed fishes (Plagopterini) of the Colorado River system. Ann Arbor, University of Michigan, Miscellaneous Publication of the Museum of Zoology 115:1-39.

Miller, R.R., J.D. Williams, and J.E. WiLliams. 1989. Extinctions of North American fishes during the past century. Fisheries 14(6):22-38.

Mueller, R.P., S.S. Southard, C.W. MaY, W.H. Pearson, AND V.I. Cullinan. 2008. Juvenile coho salmon leaping ability and behavior in an experimental culvert test bed. Transactions of the American Fisheries Society 137:941-950.

Ombredane, D., J. Baglinière, and F. Marchand. 1998. The effects of passive integrated transponder tags on survival and growth of juvenile brown trout (Salmo trutta L.) and their use for studying movement in a small river. Hydrobiologia 371/372:99-106.

PBS\&J. 2007. Geomorphic assessment of Condor Canyon. BLM Ely Field Office, Ely, NV. 39 pp.

Ruetz, C.R., III, B.M. Earl, and S.L. Kohler. 2006. Evaluating passive integrated transponder tags for marking mottled sculpins: effects on growth and mortality. Transactions of the American Fisheries Society 135:1456-1461.
Scoppettone, G.C., J.E. Harvey, and J. Heinrich. 2004a. Conservation, status, and life history of the endangered White River spinedace Lepidomeda albivallis (Cyprinidae). Western North American Naturalist 64:38-44.

Scoppettone, G.C., P.H. Rissler, and S. Shea. 2004b. A fish survey of the White River, Nevada. Western North American Naturalist 64:45-52.

Skov, C., J. Brodersen, C. Brönmark, L.A. Hansson, P. Hertonsson, AND P.A. Nilsson. 2005. Evaluation of PIT-tagging in cyprinids. Journal of Fish Biology 67:1195-1201.

Sweetser, M.G., S.D. Bryan, and A.T. Robinson. 2002. Movement, distribution, and predation: Lepidomeda vittata and nonnative salmonids in eastern Arizona. Western North American Naturalist 62:197-205.

Tibbets, C.A., A.C. Weibel, and T.E. Dowling. 2001. Population genetics of Lepidomeda vittata, the Little Colorado spinedace. Copeia 2001(3):813-819.

[USFWS] United States Fish and Wildlife Service. 1993. Big Spring spinedace, Lepidomeda mollispinis pratensis, recovery plan. Portland, OR. $42 \mathrm{pp}$.

Ward, D.L., M.R. Childs, and W.R. Persons. 2008. PIT tag retention and tag induced mortality in juvenile bonytail and Gila chub. Fisheries Management and Ecology 15:159-161.

Williams, J.E., J.E. Johnson, D.A. Hendrickson, S. Contreras-Balderas, J.D. Williams, M. NavarroMendoze, D.E. McAllister, and J.E. Deacon. 1989. Fishes of North America endangered, threatened, or of special concern. Fisheries 14(6):2-20.

Zydlewski, G.B., A. Haro, K.G. Whalen, and S.D. McCoRmick. 2001. Performance of stationary and portable passive transponder detection systems for monitoring of fish movements. Journal of Fish Biology $58: 1471-1475$.

Zydlewski, G.B., G. Horton, T. Dubreuil, B. Letcher, S. CASEY, AND J. ZYDLEWSKI. 2006. Remote monitoring of fish in small streams: a unified approach using PIT tags. Fisheries 31:492-502.

Received 25 July 2012 Accepted 27 March 2013 